\title{
Optimalisasi Limbah Ternak sebagai Pupuk Organik di Batu Mila Kecamatan Maiwa Kabupaten Enrekang, Sulawesi Selatan
}

\author{
Nurhapsa ${ }^{1 *}$, Suherman ${ }^{2}$, Irmayani $^{2}$ \\ ${ }^{1}$ Program Studi Agribisnis, Fakultas Pertanian, Universitas Muhammadiyah Parepare \\ ${ }^{2}$ Program Studi Agroteknologi, Fakultas Pertanian, Universitas Muhammadiyah Parepare
}

Submisi: 17 Juli 2018; Revisi: 12 Mei 2020; Penerimaan: 15 Mei 2020

Kata Kunci:
Kotoran kambing
Limbah
Pelatihan
Pemberdayaan
$\quad$ masyarakat
Penyuluhan
Nilai ekonomis

Keywords:

Goat feces

waste

Practice

Community

development

Counselling

Economic

value

\begin{abstract}
Abstrak Desa Batu Mila di Kecamatan Maiwa merupakan salah satu daerah penghasil jagung di Sulawesi Selatan. Untuk meningkatkan pendapatan, petani membudidayakan ternak kambing yang dikelola secara tradisional. Hal tersebut mengakibatkan banyaknya limbah dari kotoran ternak yang terbengkalai di sekitar kandang. Kegiatan pengabdian ini bertujuan untuk memberdayakan masyarakat agar dapat mengoptimalkan limbah berupa kotoran ternak menjadi pupuk organik yang bernilai ekonomi. Mitra kegiatan ini adalah Kelompok Tani Sikamaseang dan Kelompok Wanita Tani Dasawisma. Pengabdian dilaksanakan dengan metode penyuluhan dan pelatihan. Hasil pelatihan diharapkan dapat membangun kesadaran para petani untuk memanfaatkan kotoran ternak menjadi sumber pupuk organik yang dapat dimanfaatkan untuk menggantikan pupuk anorganik. Wawasan petani tentang pentingnya menjaga lingkungan diharapkan akan bertambah seiring meningkatnya pengetahuan mereka dalam memanfaatkan sumber daya alam menjadi pupuk organik.

Abstract Batu Mila Village in Maiwa District is one of the corn-producing regions in South Sulawesi. To increase income, farmers cultivate traditionally managed goat livestock, resulting in large amounts of waste from livestock manure lying around the barn. The purpose of this service was to empower the community to be able to optimize waste in the form of animal manure into organic fertilizer of economic value. The partners in this program were two farmers' groups (Sikamaseang Farmers Group and Dasawisma Women's Farmers Group). The service was carried out using counseling and training methods. The results of the training provided awareness for farmers to utilize livestock manure as a source of organic fertilizer that can be used to replace inorganic fertilizers that they often use. Farmers' insight into the importance of protecting the environment increased with their knowledge in utilizing natural resources to become organic fertilizer.
\end{abstract}

\section{PENDAHULUAN}

Pada umumnya lahan kering dimanfaatkan untuk menanam tanaman palawija, seperti padi, jagung, dan kacang-kacangan. Lahan di Desa Batu Mila termasuk kategori lahan kering sehingga petani memanfaatkan lahan tadah hujan untuk ditanami jagung atau padi. Belakangan ini terjadi penurunan produksi tanaman jagung hingga 42\% (Suherman \& Kurniawan, 2017).
Penurunan produksi tersebut diakibatkan curah hujan yang tidak menentu, serangan penyakit, serta serangan hama babi dan monyet liar ke lahan petani. Penurunan produksi jagung membuat petani mencari usaha alternatif sebagai sumber pendapatan antara lain dengan beternak kambing yang pengelolaannya masih dilakukan secara sederhana. Akan tetapi, sampai saat ini, beternak kambing belum dapat menghasilkan keuntungan. Hal ini disebabkan tingkat pendapatan

ISSN 2460-9447 (print), ISSN 2541-5883 (online)

${ }^{*}$ Corresponding author: Nurhapsa

Program Studi Agribisnis, Fakultas Pertanian, Universitas Muhammadiyah Parepare, Jl. Jend. Ahmad Yani KM. 6, Lembah Harapan, Soreang, Parepare 91131, Sulawesi Selatan, Indonesia

Email: hapsa_faktan@yahoo.co.id 
usaha ternak kurang dari 30\% (Hartono \& Purnomo, 2011).

Petani umumnya memiliki 2-5 ekor kambing yang dikandangkan dengan model kandang panggung. Pakan untuk kambing-kambing tersebut, seperti gamal, lamtoro, dan daun-daun hijau dari pepohonan di sekitar lingkungan petani (tanaman pelindung) cukup tersedia. Tanaman pelindung digunakan sebagai tanaman pagar dan penaung yang dapat bertahan dalam kekeringan. Permasalahan yang muncul dari kegiatan beternak kambing adalah menumpuknya limbah buangan, seperti kotoran ternak di bawah kandang yang diabaikan oleh petani, padahal kotoran ternak memiliki unsur hara yang bagus sehingga perlu dimanfaatkan (Syafri et al., 2017)

Kurangnya kepedulian petani untuk memanfaatkan limbah kotoran ternak menyebabkan pencemaran lingkungan permukiman akibat bau yang ditimbulkan. Asmara et al. (2013) melaporkan bahwa kotoran ternak yang tidak diolah akan menimbulkan bau yang tidak sedap, menyebabkan polusi udara serta penyakit. Wulandari et al. (2018) juga menyatakan bahwa aktivitas peternakan dapat menimbulkan polusi udara akibat bau yang menyengat dari pembentukan gas amonia yang berpengaruh buruk bagi manusia. Gas amonia dengan kadar 40 ppm mulai menyebabkan sakit kepala, mual, dan hilang nafsu makan pada manusia. Bau yang tidak sedap akibat pelepasan gas amonia tersebut dapat menurunkan kesehatan warga apabila terus diabaikan.

Petani di Desa Batu Mila memiliki pengetahuan dan keterampilan yang rendah tentang beternak kambing. Hal ini terlihat dari kurangnya teknologi yang digunakan. Mereka memahami bahwa feses ternak dapat dimanfaatkan sebagai pupuk organik, tetapi tidak memiliki pengetahuan yang cukup untuk mengolah limbah tersebut. Selain itu, mereka berpikir bahwa membuat pupuk organik membutuhkan alat dan bahan yang sulit ditemukan. Oleh karena itu, mereka beralasan untuk tidak mengelola limbah (feses) tersebut karena dianggap menyulitkan, padahal untuk menghasilkan pupuk organik dapat digunakan alat dan bahan yang sederhana dan cukup tersedia di sekitar lokasi mitra.

Telah banyak hasil penelitian yang menjelaskan bahwa limbah pertanian dapat diolah untuk menghasilkan energi yang bermanfaat. Salah satunya adalah kotoran ternak (hewan) yang dapat diolah menjadi biogas dari hasil fermentasi bakteri anaerob (Wahyono \& Sudarmo, 2012; Wulandari et al., 2016). Limbah dari bahan organik diolah menjadi pupuk organik untuk meningkatkan nilai ekonomisnya (Yuliani \& Nugraheni, 2010). Pembuatan pupuk organik tidak terlalu sulit. Teknologi sederhana dalam membuat pupuk adalah dengan cara menumpuk dan membalik-balikannya (Suniantara et al., 2019). Pengolahan limbah menjadi pupuk organik cukup aman dan proses pembuatannya tidak terlalu rumit sehingga dapat dibuat sendiri oleh masyarakat dengan bahan baku sederhana yang mudah dijumpai (Yuliani \& Nugraheni, 2010). Kualitas pupuk organik bervariasi dan sumber bahan untuk pupuk organik juga sangat beragam, seperti limbah pertanian dengan karakteristik bahan organik yang bermacam-macam (Hartatik \& Setyorini, 2012).

Kelompok tani dapat membuat pupuk organik padat secara mandiri dengan memanfaatkan limbah kotoran ternak yang diperoleh di sekitar kandang (Smara et al., 2017). Limbah organik yang tidak diolah dapat menimbulkan pencemaran sehingga perlu dimanfaatkan (Desiana et al., 2013). Limbah berupa kotoran, urin, dan sisa pakan kambing dapat menimbulkan pencemaran udara dan berkumpulnya sarang lalat yang dikhawatirkan akan menimbulkan penyakit (Darmawan \& Astuti, 2018). Oleh karena itu, peternak disarankan untuk mengolah limbah guna mengurangi polusi (Wulandari et al., 2016). Salah satu solusi terbaik yang dapat dilakukan adalah dengan mengolah limbah menjadi pupuk organik. Pengolahan tersebut dapat menghindari terjadinya pencemaran dan menciptakan produk berupa pupuk organik yang dapat dimanfaatkan sendiri oleh masyarakat atau dijual.

Berdasarkan latar belakang tersebut terdapat beberapa permasalahan yang teridentifikasi, yaitu (a) mitra belum mengetahui teknologi sederhana dalam mengolah limbah ternak menjadi pupuk organik yang bernilai ekonomis serta (b) kurangnya kesadaran mitra akan dampak pencemaran gas amonia terhadap kesehatan. Kegiatan ini bertujuan untuk (a) meningkatkan kapasitas peternak dalam mengoptimalkan pemanfaatan limbah ternak kambing menjadi pupuk organik, (b) untuk mengurangi pencemaran lingkungan yang ditimbulkan limbah ternak, dan (c) untuk memperoleh nilai ekonomis dari hasil pengolahan limbah tersebut. Tentama et al. (2018) mengatakan bahwa limbah peternakan dapat mendukung perekonomian petani serta mengurangi pengeluaran untuk pembelian pupuk buatan.

\section{METODE}

Kegiatan pengabdian ini dilaksanakan di Desa Batu Mila, Kecamatan Maiwa, Kabupaten Enrekang, Sulawesi Selatan. Petani di Desa Batu Mila adalah petani lahan kering yang sering mengalami kerugian akibat gagal panen karena kekeringan. Hal tersebut mendorong sebagian petani untuk beternak sebagai usaha sampingan meskipun belum menjanjikan. Mitra dalam kegiatan pengabdian ini adalah Kelompok Tani Sikamaseang dan Kelompok Tani Dasawisma. 
Kelompok tani yang dipilih merupakan kelompok petani lahan kering yang memiliki ternak kambing dikandangkan. Kegiatan pengabdian dilaksanakan pada April sampai Agustus 2018.

Kegiatan pengabdian ini menggunakan dua metode pendekatan, yaitu penyuluhan dan pelatihan. Tahap penyuluhan dilakukan dengan memberikan materi tentang pemanfaatan limbah dan potensi nilai ekonomi serta hasil pengolahan limbah dan penyuluhan tentang pentingnya mengelola limbah. Tahap pelatihan dilakukan di lapangan dengan mendemonstrasikan cara pembuatan pupuk organik menggunakan teknologi sederhana dan tepat guna.

\subsection{Tahap penyuluhan}

Penyuluhan dilakukan sebagai awal pelaksanaan program. Penyuluhan bertujuan untuk (a) penyamaan persepsi, (b) menggali informasi tentang kebutuhan mitra pengabdian, serta (c) mengubah pola pikir mitra. Selain penyuluhan, dilakukan diskusi untuk mendalami permasalahan yang dihadapi mitra serta mengetahui bagaimana pengelolaan masalah yang ada di sekitar lingkungannya. Penyuluhan dilaksanakan di balai pertemuan kelompok tani di Dusun Botto Dengeng, Desa Batu Mila. Pelaksanaan penyuluhan dirangkai dengan kegiatan rutin bulanan yang dilaksanakan oleh mitra agar diskusi dan penyampaian informasi dapat diikuti oleh semua anggota kelompok dari kedua mitra. Materi penyuluhan meliputi pencemaran limbah pertanian sebagai sumber penyakit, pemanfaatan/ pengolahan limbah bernilai ekonomis, dan pembuatan pupuk organik dengan metode sederhana.

\subsection{Tahap pelatihan}

Tahap pelatihan merupakan kegiatan aplikatif, yakni pembuatan pupuk organik dari limbah ternak (terutama dari kotoran kambing). Pelatihan dilaksanakan di salah satu kandang peternak yang menjadi mitra dan diikuti oleh semua anggota mitra. Pembuatan pupuk dilaksanakan oleh tim pelaksana dan mitra dengan praktik langsung di sekitar kandang. Pelatihan disertai dengan penjelasan singkat tentang penggunaan alat dan bahan yang tersedia di wilayah mitra agar mudah dalam pengaplikasiannya.

Pembuatan pupuk organik terdiri atas beberapa tahap. Tahap pertama adalah penyediaan bahan dan alat. Bahan yang digunakan adalah kotoran kambing, aktivator mikroorganisme (dekomposer), air, dan molasses (gula). Adapun alat yang digunakan adalah drum/ember plastik (reaktor), gayung, dan ember. Tahap kedua adalah penyiapan desain reaktor (desain reaktor dapat dilihat pada Gambar 1). Tahap ketiga adalah proses pembuatan yang melibatkan partisipasi mitra (Gambar 2). Berikut ini beberapa prosedur dalam proses pembuatan pupuk organik. a) Wadah berupa drum/ember dan penutupnya disiapkan. Tutup ember diberi lubang untuk memasukkan pipa aerasi.

b) Pipa aerasi dibuat sesuai dengan ketinggian drum/ember dan diberi lubang-lubang aerasi pada bagian bawah pipa.

c) Molasses (gula) dilarutkan ke dalam air dengan perbandingan 1:1 dan diaduk hingga rata.

d) Aktivator mikroorganisme (dekomposer) dilarutkan ke dalam larutan molasses yang sudah jadi dan didiamkan selama beberapa menit

e) Kotoran kambing disiram dengan larutan mikroba dekomposer secara perlahan dan merata sampai kadar air $\pm 40 \%$. Kotoran kambing kemudian dimasukkan ke dalam drum/ember.

f) Kotoran kambing didiamkan dan setiap satu minggu dilakukan pembalikan.

g) Ciri pupuk organik dari kotoran kambing yang telah jadi adalah pupuk tidak berbau busuk/ menyengat dan ditumbuhi jamur berupa hifa berwarna putih.

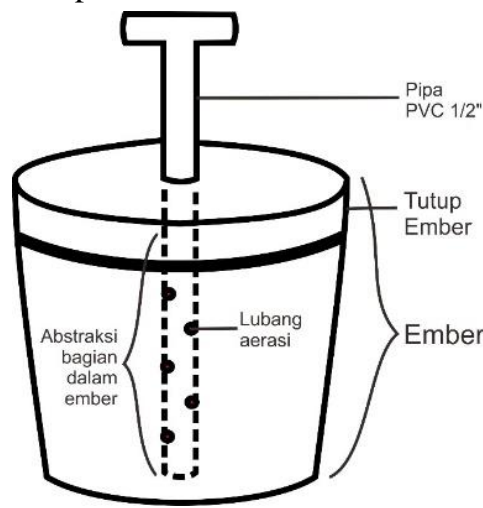

Gambar 1. Desain reaktor sederhana

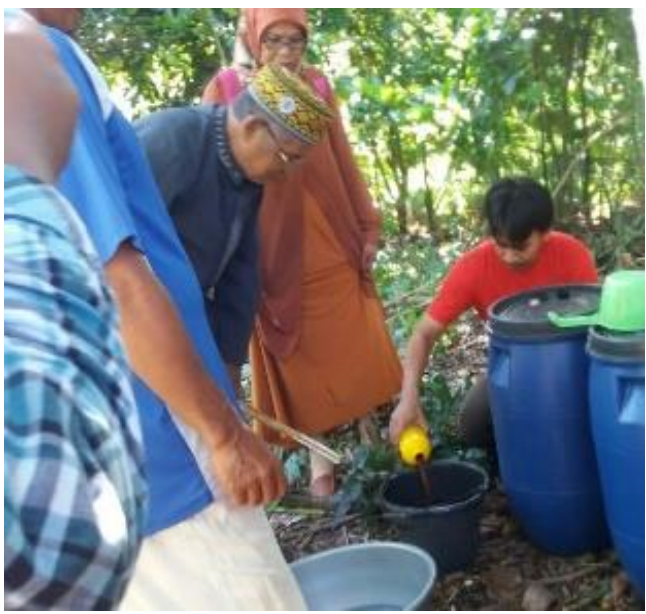

Gambar 2. Praktik pembuatan pupuk oleh tim pelaksana dengan kelompok mitra

\section{HASIL DAN PEMBAHASAN}

Realisasi pelaksanaan program pengabdian ini berupa penyuluhan dan pelatihan. Tahap penyuluhan dilakukan dengan memberikan materi tentang 
pemanfaatan limbah dan potensi nilai ekonomi dari hasil pengolahan limbah, sedangkan tahap pelatihan dilakukan dengan mendemonstrasikan cara pembuatan pupuk organik menggunakan teknologi sederhana dan tepat guna.

\subsection{Pelaksanaan penyuluhan}

Pelaksanaan kegiatan diawali dengan inventarisasi kebutuhan mitra untuk menyiapkan materi yang sesuai dengan kebutuhan mitra. Dari hasil observasi lapangan diperoleh informasi bahwa umur dan tingkat pendidikan anggota dari kedua mitra bervariasi. Sebagian besar umur anggota berada pada kisaran 40-60 tahun (70\%). Tiga puluh persen anggota berumur 30 tahunan dan $20 \%$ anggota berumur di bawah 30 tahun. Ali et al. (2013) menjelaskan bahwa tingkat pendidikan berperan penting dalam mengubah masyarakat untuk mengadopsi inovasi baru. Oleh karena itu, dibutuhkan suatu pendekatan penyuluhan dengan metode yang lebih komunikatif agar dapat memikat serta memotivasi mitra. Ali et al. (2013) mengatakan bahwa penyuluhan bertujuan untuk meningkatkan motivasi peserta sehingga dapat mempraktikkan materi dan memudahkan pembimbingan perorangan bagi peserta yang berminat.

Pelaksanaan penyuluhan dikoordinasikan dengan petugas penyuluh setempat dan ketua kelompok masing-masing mitra. Penyuluhan dilaksanakan secara formal, yaitu dengan mengumpulkan petani (peternak) di balai pertemuan dan secara informal, yaitu tim pelaksana melakukan kunjungan (Widiastuti, 2015). Berdasarkan hasil koordinasi ditetapkan bahwa kebutuhan mitra adalah materi yang menjelaskan manfaat dan nilai pengolahan limbah ternak menjadi produk yang bermanfaat, seperti pupuk organik. Materi penyuluhan meliputi manajemen pengelolaan ternak yang baik dan benar, penanganan limbah peternakan menjadi pupuk organik, cemaran limbah peternakan terhadap kesehatan lingkungan, dan penerapan teknologi sederhana dalam pembuatan pupuk organik.

Penyuluhan dalam bentuk pertemuan kelompok dilaksanakan satu kali sebulan agar tidak mengganggu aktivitas sehari-hari. Penyampaian materi penyuluhan disertai dengan diskusi untuk mendukung dan merangsang partisipasi aktif peserta. Akan tetapi, peserta kurang antusias dalam mengikuti diskusi. Hal ini menjadi kendala utama yang dihadapi dalam pelaksanaan penyuluhan. Hasil diskusi pertama yang disepakati untuk dilakukan adalah cara mengolah limbah ternak (kotoran kambing) agar tidak terbengkalai dan meninggalkan bau busuk serta menjaga kesehatan lingkungan permukiman petani.

\subsection{Pelaksanaan pelatihan}

Pelatihan dilaksanakan dengan demonstrasi langsung di rumah petani yang dekat dengan kandang ternak untuk memudahkan kontrol dan evaluasi. Demonstrasi yang dilakukan adalah pembuatan pupuk organik padat bersumber dari kotoran kambing. Limbah kotoran kambing cukup tersedia, tetapi kurang dimanfaatkan untuk menjadi pupuk kompos dan atau bokashi. Oleh karena itu, praktik dalam kegiatan ini cukup dengan memanfaatkan kotoran yang sudah ada. Praktik pengenalan teknologi ini dilakukan dengan metode sederhana sesuai dengan kemampuan mitra. Beberapa bahan penunjang yang digunakan adalah aktivator mikroorganisme dan molasses.

Pupuk organik yang sudah jadi pada minggu pertama biasanya ditumbuhi jamur dan masih berbau menyengat karena pelepasan gas amonia. Pupuk yang siap dipanen adalah pupuk yang sudah difermentasi dan mengalami pembalikan hingga kurang lebih satu bulan (Suherman \& Kurniawan, 2017). Perubahan tampakan pupuk tiap minggu disajikan dalam Tabel 1.

Berdasarkan hasil pengamatan diketahui bahwa pada minggu pertama dan kedua tidak terjadi fermentasi secara merata. Hal itu disebabkan karena tingginya kandungan air di bagian bawah, sedangkan bagian atas tampak kering. Peternak memerlukan pengetahuan yang memadai untuk melakukan pembalikan secara rutin yang tidak hanya berdasarkan perhitungan hari, tetapi juga melihat kondisi bahan agar fermentasi berlangsung dengan baik. Proses fermentasi juga dipengaruhi oleh kondisi lingkungan setempat yang memiliki rata-rata suhu mencapai $29^{\circ} \mathrm{C}$ pada siang hari. Hal tersebut membuat permukaan atas mengalami penguapan yang tinggi. Pemahaman akan pentingnya pembalikan dan pemantauan kondisi pupuk organik secara rutin ditekankan kepada mitra. Pada minggu keempat, pupuk hasil fermentasi tidak lagi menimbulkan bau menyengat, tetapi masih membutuhkan waktu agar jamur tumbuh merata (Gambar 3).

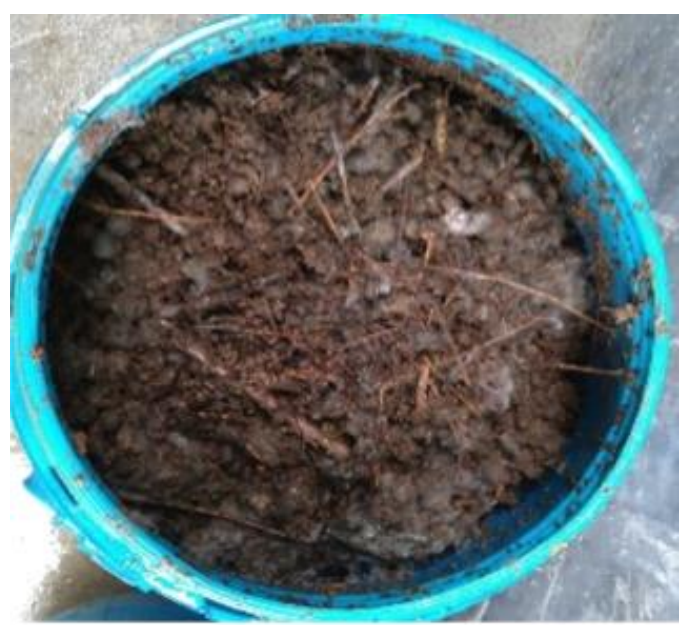

Gambar 3. Pupuk organik hasil fermentasi 
Tabel 1. Pengamatan hasil kegiatan pelatihan pembuatan pupuk organik tiap minggu

\begin{tabular}{|c|c|c|}
\hline $\begin{array}{c}\text { Waktu pengamatan } \\
\text { (Minggu) }\end{array}$ & Hasil pengamatan & Keterangan \\
\hline $\mathrm{I}$ & $\begin{array}{l}\text { Kotoran yang terdekomposisi } \\
\text { ditumbuhi jamur putih pada } \\
\text { permukaan. } \\
\text { Bagian bawah masih mengeluarkan } \\
\text { bau menyengat. }\end{array}$ & $\begin{array}{l}\text { Dibutuhkan pembalikan secara rutin karena } \\
\text { bagian bawah masih lebih basah dibandingkan } \\
\text { dengan bagian permukaan dan perlu dijaga } \\
\text { kelembapannya. }\end{array}$ \\
\hline II & $\begin{array}{l}\text { Masih mengeluarkan bau, tetapi tidak } \\
\text { menyengat. } \\
\text { Masih terdapat kotoran yang } \\
\text { menggumpal dan tidak mengalami } \\
\text { perubahan warna. }\end{array}$ & $\begin{array}{l}\text { Pembalikan dilakukan secara rutin dan } \\
\text { kelembapan tetap dijaga karena bagian atas } \\
\text { tampak lebih kering. }\end{array}$ \\
\hline III & $\begin{array}{l}\text { Tidak didapatkan bau menyengat, } \\
\text { tetapi bagian bawah tidak } \\
\text { memperlihatkan perubahan warna. }\end{array}$ & $\begin{array}{l}\text { Kondisi pupuk tampak agak kering sehingga perlu } \\
\text { penyiraman, tetapi kadar air perlu dijaga } \pm 40 \% \text {. }\end{array}$ \\
\hline IV & $\begin{array}{l}\text { Pupuk sudah tidak berbau menyengat. } \\
\text { Sebagian besar kotoran telah } \\
\text { ditumbuhi jamur berwarna putih. }\end{array}$ & $\begin{array}{l}\text { Masih dibutuhkan waktu untuk fermentasi agar } \\
\text { jamur tumbuh merata. }\end{array}$ \\
\hline
\end{tabular}

\subsection{Kelemahan pelaksanaan program}

Berdasarkan hasil pemantauan pelaksanaan kegiatan diketahui bahwa pupuk organik yang diperoleh tidak sesuai dengan yang diharapkan. Pembuatan pupuk organik yang dilakukan sebelumnya berlangsung selama satu bulan. Akan tetapi, realisasi di lapangan berlangsung lebih dari 1,5 bulan. Dalam proses pembuatan pupuk organik sebaiknya dilakukan penghalusan kotoran kambing agar dekomposisi terjadi lebih cepat. Hal tersebut seperti yang dilakukan oleh Ilham dan Mukhtar (2018), yaitu pembuatan pupuk organik dari kotoran kambing yang dilakukan dengan terlebih dahulu menghancurkan kotoran kambing hingga halus kemudian mencampurnya dengan mikroorganisme sampai tercapai kadar air 40\%. Selain itu, kurangnya usaha petani untuk mencari bahan tambahan seperti dedak atau bekatul dan dolomit menyebabkan proses dekomposisi berlangsung lebih lama.

\section{KESIMPULAN}

Penyuluhan dan pelatihan pembuatan pupuk organik dari kotoran kambing dengan metode sederhana dapat meningkatkan pengetahuan dan pemahaman petani (peternak) mengenai pembuatan pupuk organik. Petani telah menyadari bahwa limbah yang dibiarkan dapat menyebabkan masalah lingkungan dan kesehatan. Penyuluhan dan pelatihan yang dilakukan membangkitkan kesadaran petani untuk memanfaatkan media yang tersedia, yaitu kotoran ternak untuk diolah menjadi pupuk organik yang dapat dimanfaatkan guna menggantikan pupuk anorganik. Selain itu, kesadaran petani akan pentingnya mengolah limbah mendorong mereka untuk menjaga kesehatan, baik kesehatan pribadi maupun kesehatan di lingkungan sekitar.

\section{UCAPAN TERIMA KASIH}

Terima kasih penulis sampaikan kepada Kelompok Tani Sikamaseang dan Kelompok Tani Dasawisma di Desa Batu Mila, Kecamatan Maiwa, Kabupaten Enrekang, Sulawesi Selatan yang telah mengikuti kegiatan penyuluhan dan pelatihan ini.

\section{REFERENSI}

Ali, U., Sumartono, \& Humaidah, N. (2013). Pembinaan Masyarakat Tani Peternak Kambing dan Domba di Desa Sumbersekar, Kecamatan Dau, Kabupaten Malang. Jurnal Dedikasi, 9, 60-66. DOI:10.22219/dedikasi.v9i0.1387

Asmara, A., Hutagaol, M. P., \& Salundik, S. (2013). Analisis Potensi Produksi dan Persepsi Masyarakat dalam Pengembangan Biogas pada Sentra Usaha Ternak Sapi Perah di Kabupaten Bogor. Jurnal Agribisnis Indonesia, 1(1), 71-80. DOI:10.29244/jai.2013.1.1.71-80

Darmawan, E. \& Astuti, W. (2018). PKM bagi Kelompok Ternak Kambing Peranakan Etawa (PE) Di Kecamatan Samigaluh Kabupaten Kulonprogo. Prosiding Seminar Pengabdian kepada Masyarakat (SENADIMAS), 376-380.

Desiana, C., Banuwa, I. S., Evizal, R., \& Yusnaini, S. (2013). Pengaruh Pupuk Organik Cair Urine Sapi dan Limbah Tahu terhadap Pertumbuhan Bibit Kakao (Theobroma cacao L.). Jurnal Agrotek Tropika, 1(1), 113-119. DOI:10.23960/jat.v1i1.1927 
Hartatik, W. \& Setyorini, D. (2012). Pemanfaatan Pupuk Organik untuk Meningkatkan Kesuburan Tanah dan Kualitas Tanaman. Badan Penelitian Litbang Pertanian Balai Penelitian Tanah. Bogor. Prosiding Seminar Nasional Teknologi Pemupukan dan Pemulihan Lahan Terdegradasi, 571-582.

Ilham, F. \& Mukhtar, M. (2018). Perbaikan Manajemen Pemeliharaan Dalam Rangka Mendukung Pembibitan Kambing Kacang Bagi Warga di Kecamatan Bone Pantai Kabupaten Bone Bolango. Jurnal Pengabdian kepada Masyarakat (Indonesian Journal of Community Engagement), 3(2), 141-152. DOI:10.22146/jpkm.29265

Smara, N. K. M. G., Suardi, I. D. P. O., \& Agung, I. D. G. (2017). Peranan Penyuluh Pertanian Lapangan dalam Pembuatan Pupuk Organik Padat (Kasus pada Kelompok Ternak Putra Kertha Santhi, Lingkungan Kebon, Kelurahan Baler Bale Agung, Kecamatan Negara, Kabupaten Jembrana). Jurnal Agribisnis dan Agrowisata (Journal of Agribusiness and Agritourism), 6(1), 11-20. DOI:10.24843/JAA.2017.v06.i01.p02

Suherman, S. \& Kurniawan, E. (2017). Manajemen Pengelolaan Ternak Kambing di Desa Batu Mila sebagai Pendapatan Tambahan Petani Lahan Kering. Jurnal Dedikasi Masyarakat, 1(1), 713. DOI:10.31850/jdm.v1i1.246
Suniantara, I. K. P., Putra, I. G. E. W., \& Ayuni, N. P. S. (2019). Pengolahan Pupuk Organik Padat dari Limbah Biogas pada Kelompok Ternak Sedana Murti. SINDIMAS, 1(1), 133-138. DOI:10.30700/sm.v1i1.551

Syafri, R., Hilma, R., Nst, H., \& Pras, P. (2017). Pelatihan Pembuatan Pupuk Organik Cair bagi Kelompok Tani Desa Kartama Pekanbaru. Jurnal Pengabdian UntukMu NegeRI, 1(1), 13-18. DOI:10.37859/jpumri.v1i1.28

Tentama, F., Maulana, M., \& Anggraeni, R. (2018). Pemberdayaan Masyarakat dalam Pemanfaatan Limbah Pertanian sebagai Bioenergi Alternatif, Media Tanam, dan Pupuk Organik. Jurnal Pemberdayaan: Publikasi Hasil Pengabdian Kepada Masyarakat, 1(2), 367-374. DOI:10.12928/jp.v1i2.367

Wahyono, E. H. \& Sudarmo, N. (2012). Biogas Energi Ramah Lingkungan. Bogor: Developing Collaborative Manajement of Cibodas Biosphere Reserve West Java.

Widiastuti, A. (2015). Pendampingan Petani Stroberi di Desa Serang, Karangreja, Purbalingga, Jawa Tengah dalam Manajemen Kesehatan Tanaman Melalui KKN-PPM Universitas Gadjah Mada: Perlunya Bibit Stroberi Sehat dan Peningkatan Keterlibatan Petani dalam Kegiatan Kelompok. Jurnal Pengabdian kepada Masyarakat (Indonesian Journal of Community Engagement), 1(1). DOI:10.22146/jpkm.16953 